\title{
Distortion of the SPAD 502 chlorophyll meter readings by changes in irradiance and leaf water status
}

\author{
Dana E. MARTínEZ, Juan J. GUIAMET* \\ Instituto de Fisiología Vegetal, Universidad Nacional de La Plata, cc 327, 1900-La Plata, Argentina
}

(Received 27 Fevrier 2003; accepted 1st December 2003)

\begin{abstract}
The SPAD 502 Chlorophyll Meter can estimate leaf chlorophyll content as a surrogate measure of the nitrogen (N) status of plants, and therefore, it can be used to assess the $\mathrm{N}$ requirements of crops. In this work, we show that irradiance, leaf water status and time of measurement (i.e., morning vs. afternoon), may interfere with the SPAD 502 measurements. SPAD values increased by 2-3 units as relative leaf water content decreased from 94 to $87.5 \%$ in wheat leaves. A change in irradiance (from 1100 to $600-650 \mu \mathrm{mol} \mathrm{m}^{-2} \mathrm{~s}^{-1}$ ) caused an increase of about 2 SPAD units in potted maize plants. Throughout the day, SPAD values varied by up to 4 units in well-watered plants of maize growing under field conditions. The slope of the response of the SPAD meter to chlorophyll content was steeper in the morning than in the afternoon. Since the range of SPAD values that may separate $\mathrm{N}$ deficiency from $\mathrm{N}$ surplus in a crop are often relatively narrow, time of measurement, irradiance and plant water status must be taken into account to precisely monitor crop N needs with the SPAD 502.
\end{abstract}

chlorophyll meter / irradiance / maize / nitrogen / relative water content / SPAD 502 / wheat

Résumé - Effet de l'irradiance et de l'eau foliaire sur la mesure de la chlorophylle avec le SPAD 502. La mesure de la quantité de chlorophylle permet d'estimer la quantité d'azote des plantes, et donc la quantité d'azote à apporter aux cultures. Ici, nous montrons que l'irradiance, l'état hydrique des feuilles ainsi que le moment de la mesure (matin, après-midi) interfèrent avec la mesure de la quantité de chlorophylle.

chlorophylle / irradiance / eau / feuille / maïs / N / SPAD / blé

\section{INTRODUCTION}

The SPAD 502 Chlorophyll Meter was developed to measure the chlorophyll $(\mathrm{Chl})$ content of leaves, and thereby, to estimate indirectly the nitrogen status of plants. This instrument measures transmittance by leaves at two wavelengths $(650 \mathrm{~nm}$ and $940 \mathrm{~nm})$ that are differentially absorbed by chlorophyll $[16,18]$. Since it is a non-destructive method providing results immediately, its use has increased steadily in recent years, especially as an aid in determining crop $\mathrm{N}$ requirements.

Earl and Tollenaar [7] found a close correlation $\left(R^{2}=0.98\right)$ between SPAD readings and maize leaf absorptance in the field, and Adamsem et al. [1] compared SPAD readings with "greenness" measurements taken with a digital camera during wheat senescence $\left(R^{2}=0.91\right)$. Generally, there is a close correlation between SPAD readings and leaf $\mathrm{Chl}$ or $\mathrm{N}$ content [4, $15,17,19,20,27]$. The applications of the SPAD 502 are not limited to the estimation of $\mathrm{Chl}$ and $\mathrm{N}$ content. Araus et al. [2] proposed that SPAD meter readings could be a surrogate of carbon isotope discrimination measurements to estimate water-use efficiency in barley. Since leaf SPAD values are closely related to leaf $\mathrm{N}$ content, the SPAD meter can be used to monitor the $\mathrm{N}$ status of crops and, thereby, to adjust the rates of $\mathrm{N}$ fertilization in order to increase $\mathrm{N}$-use efficiency or to achieve higher yields, e.g., in maize, wheat, rice and tobacco $[11,17,22,25]$. Several studies have sought to establish critical SPAD readings below which crop yield responds to $\mathrm{N}$ fertilization. For example, 52-56 SPAD units at the $1 / 4$ milk line stage was defined as a critical range separating $\mathrm{N}$ sufficiency from $\mathrm{N}$ deficiency in maize [23]. Similarly, in some experiments, readings below 35,32 and 45 SPAD units indicated the need for $\mathrm{N}$ fertilization in rice, wheat and cotton, respectively $[22,27,31]$. In contrast to the use of fixed SPAD values to assess the $\mathrm{N}$ status of crops, other works have concentrated on establishing $\mathrm{N}$ sufficiency indexes (i.e., the ratio between SPAD readings in the tested field vs. SPAD readings in a heavily-fertilized reference strip). For example, topdressing $\mathrm{N}$ fertilizer every time the $\mathrm{N}$ sufficiency index fell below 0.90 increased agronomic $\mathrm{N}$-use efficiency in rice [11].

Whether fixed SPAD values or sufficiency indexes are used, SPAD-based management of $\mathrm{N}$ fertilization requires that SPAD readings are precise and reproducible. However, leaf physiological traits such as cell structure, chloroplast movements and water status can have important effects on leaf optical properties $[6,8,13,14,21,26]$ and, therefore, on SPAD

* Corresponding author: j.guiamet@museo.fcnym.unlp.edu.ar 
values. For example, changes in irradiance, at least at low irradiances, can cause light-dependent chloroplast movements that change leaf absorptance [e.g., 14, 26] and, thereby, SPAD readings [10]. However, there is not enough information on the sensitivity of SPAD readings to the changes in environmental conditions that usually occur throughout the day (e.g., changes in irradiance), or to fluctuations in leaf physiological conditions (e.g., water status). This prompted us to test the accuracy and reproducibility of the SPAD 502 Chlorophyll Meter measurements in relation to the time of the day, irradiance, and changes in leaf water status.

\section{MATERIALS AND METHODS}

\subsection{Plant material}

Plants of wheat (Triticum aestivum L.) cv. Bonaerense Redomón and maize (Zea mays L.) hybrid AX840 were grown in 4-liter pots under a rain shelter in La Plata (34 $\left.{ }^{\circ} 54^{\prime} \mathrm{S}\right)$ during the normal growing season for each crop in Argentina. The pots were watered twice a day to maintain the soil at field capacity. Additionally, field measurements were made on a maize (hybrid Pucará) crop grown at the experimental station of the Universidad Nacional de La Plata (34 $4^{\circ} 54^{\prime}$ S) under two $\mathrm{N}$ fertilization regimes $\left(0\right.$ and $90 \mathrm{~kg} \mathrm{~N}^{-1}$ applied at planting). All the experiments were carried out with plants at the vegetative stage. Measurements were made on the third fully expanded leaf counting from the top in maize, and on the flag leaf of wheat.

\subsection{Measurements}

Chlorophyll (Chl) content was measured non-destructively with the portable SPAD 502 Chlorophyll Meter (Minolta Co., Ltd.), and spectrophotometrically after extraction of chlorophyll with $N, N$-dimethylformamide [12]. During measurements with the SPAD 502, the sensor head was shaded with the operator's own body as recommended by the manufacturer to avoid direct sunlight from reaching the instrument. In all experiments, the spot of the leaf measured with the SPAD 502 was marked with White Out dashes made parallel to the lateral grooves of the sensor head, so that exactly the same spot could be either measured again later with the SPAD-502 or excised for extraction and spectrophotometric determination of Chl. Leaf water status was assessed by determining relative water content $(\mathrm{RWC}=$ fresh weight - dry weight/full turgor weight - dry weight) [28]. Irradiance was measured with a Licor Li1000 Data Logger fitted with a Licor Quantum Sensor, or with a Groweather Weather Station (Davis Instruments, Corp) in the case of the field experiment.

\subsection{Effects of leaf water content on SPAD readings}

To determine the effects of leaf water content, potted wheat plants were transported to the laboratory early in the morning, and leaf segments $(5 \mathrm{~cm}$ long) were excised and subjected to a controlled dehydration/rehydration experiment. SPAD and fresh weight measurements were made on leaf segments at different times throughout the experiment, under dim light (about $\left.10 \mu \mathrm{mol} \mathrm{m} \mathrm{m}^{-2} \mathrm{~s}^{-1}\right)$. Segments were allowed to dehydrate on the bench for 45 minutes, and then allowed to rehydrate to full turgor for about $4 \mathrm{~h}$ in distilled water. Then, the segments were dried for 48 hs before determining the dry weight to calculate RWC. Chl was extracted and determined spectrophotometrically from disks $(5 \mathrm{~mm}$ diameter) excised at the start of the experiment from an area of the leaf blade adjacent to the segments used for the dehydration/rehydration experiments.

\subsection{Irradiance effects on SPAD readings}

To assess the effects of irradiance on SPAD readings, measurements were taken at midday under sunlight (1100 $\mu$ mol photons $\mathrm{m}^{-2} \mathrm{~s}^{-1}$, air temperature $=29^{\circ} \mathrm{C}$ ) on maize plants growing in pots. Thereafter, the pots were moved under a neutral density shade $\left(600-650 \mu \mathrm{mol}\right.$ photons $\mathrm{m}^{-2} \mathrm{~s}^{-1}$, air temperature $=27-$ $28^{\circ} \mathrm{C}$ ) and three hours later SPAD measurements were taken again on the same spot where the leaves had been measured the first time.

\subsection{Daytime variations in SPAD readings}

Diurnal variations in SPAD meter readings were determined in maize plants growing in pots or in the field, and measured in the morning and afternoon on the same day. Leaves were measured with the SPAD 502 on the mid-portion of the leaf blade, $2 \mathrm{~cm}$ away from the leaf margin, marked with White Out, and the whole leaf was excised and placed in a black polyethylene bag. The leaves were transported immediately to a nearby laboratory to determine RWC and excise a disk $\left(0.2 \mathrm{~cm}^{2}\right)$ for $\mathrm{Chl}$ extraction and spectrophotometric determination. Measurements were taken in the early morning (09:00 am) and in the afternoon $(03: 30 \mathrm{pm})$ for potted plants, or at mid-morning $(10: 30 \mathrm{am})$ and two hours after midday $(02: 00 \mathrm{pm})$ in the field experiment.

\section{RESULTS}

\subsection{Influence of leaf water content on SPAD measurements}

To study the effects of leaf turgor (i.e., RWC) on SPAD measurements, wheat leaves were excised and subjected to a controlled dehydration/rehydration experiment in the lab. A decrease in RWC from 94.0 to $87.5 \%$ caused SPAD readings to increase from $44.3 \pm 1.5$ to $47.2 \pm 1.5$ SPAD units (Tab. I). Conversely, re-watering the segments for $4 \mathrm{~h}$ to achieve full turgor brought SPAD readings back to values that were identical to those recorded in fresh segments before the dehydration treatment (i.e., $44.1 \pm 1.4$ SPAD units). Thus, relatively modest changes in leaf water content can cause variations in SPAD readings of more than 2 units. However, the fact that SPAD readings were the same in fully-hydrated leaves and in leaves with a RWC $=94 \%$ suggests that interference by changes in RWC occurs only below a threshold RWC level. Although RWC interfered with SPAD readings, leaf turgor did not affect the sensitivity/response of the SPAD meter towards differences in Chl content (Fig. 1). A close linear relationship between SPAD values and extracted $\mathrm{Chl}$ content was obtained 
Table I. Changes in SPAD 502 readings in response to variations in leaf water content. Flag leaves were detached from wheat plants early in the morning, and relative water content and SPAD readings were measured as the leaves were allowed to dehydrate, and then to rehydrate back to full turgor in distilled water in the lab. Values between parentheses represent the standard error of the mean $(n=15)$. Means followed by the same letter are not significantly different from those of fresh leaves at $P<0.05$ (paired t-test comparisons). *RWC of fullyrehydrated leaves.

\begin{tabular}{lccc}
\hline & $\begin{array}{c}\text { Time after } \\
\text { detachment (min) }\end{array}$ & $\begin{array}{c}\text { Relative water } \\
\text { content, RWC \% }\end{array}$ & SPAD units \\
\hline $\begin{array}{l}\text { Fresh leaves } \\
\begin{array}{l}\text { Dehydrated } \\
\text { segments }\end{array}\end{array}$ & 0 & $94.0(1.2) \mathrm{a}$ & $44.3(1.5) \mathrm{a}$ \\
$\begin{array}{l}\text { Fully re-hydrated } \\
\text { segments }\end{array}$ & 285 & $87.5(2.2) \mathrm{b}$ & $47.2(1.5) \mathrm{b}$ \\
\hline
\end{tabular}

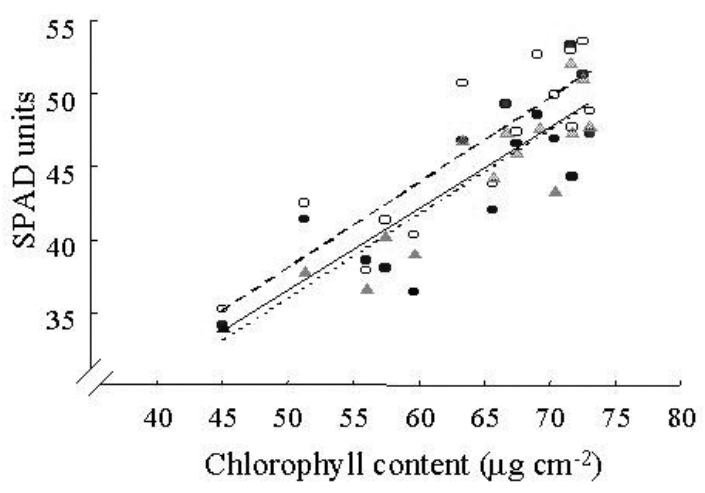

Figure 1. The effects of relative water content (RWC) on the relationship between extractable chlorophyll content and SPAD readings in wheat leaves. SPAD readings were made on fresh leaves (mean RWC $=94 \%$, filled circles, continuous line, $y=0.56 x+8.54$, $\left.\mathrm{R}^{2}=0.69\right)$, dehydrated segments $(\mathrm{RWC}=87 \%$, empty circles, dashed line, $\left.\mathrm{y}=0.49 \mathrm{x}+15.48, \mathrm{R}^{2}=0.68\right)$ and dehydrated segments allowed to rehydrate in distilled water for $4 \mathrm{~h}$ (filled triangles, dotted line, $\left.y=0.58 x+6.85, R^{2}=0.83\right)$.

for all levels of leaf turgor, and the slope of the regression lines between extracted Chl content and SPAD values did not vary significantly with changes in RWC. The main effect of RWC was on the intercept value, which increased substantially in dehydrated segments (Fig. 1).

\subsection{Irradiance effects on SPAD readings}

Irradiance changes substantially between early morning and early afternoon, particularly under clear skies. Maize plants grown in pots in an open, sunny area were measured with the SPAD meter at midday under direct sunlight $\left(1100 \mu \mathrm{mol}\right.$ photons $\left.\mathrm{m}^{-2} \mathrm{~s}^{-1}\right)$. The leaf was identified, the measured part of the blade was marked and the plants were moved under a shade $\left(600-650 \mu \mathrm{mol}\right.$ photons $\left.\mathrm{m}^{-2} \mathrm{~s}^{-1}\right)$. Three hours later the leaves were measured again on the same spot where they had been measured the first time. The average SPAD value was $25.55 \pm 0.37$ in plants measured under sunlight, but this increased to $26.9 \pm 0.39$ after transfer to the shade $(P<0.05$ in a paired t-test comparison) (Fig. 2).

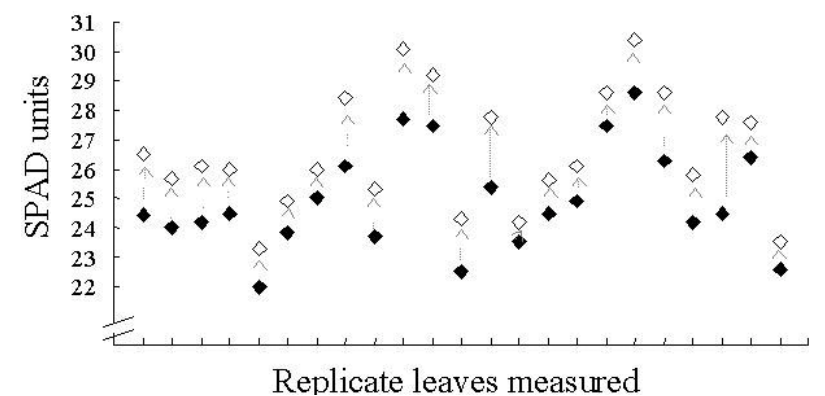

Figure 2. Changes in SPAD readings in maize plants transferred from high $\left(1100 \mu \mathrm{mol} \mathrm{m} \mathrm{m}^{-2}\right.$, closed diamonds) to moderate $(600-$ $650 \mu \mathrm{mol} \mathrm{m} \mathrm{m}^{-1}$ photosynthetically active radiation, empty diamonds) irradiance. Horizontal lines represent the mean SPAD reading for leaves measured under high (continuous line) or moderate (dotted line) irradiance. Each leaf measured is placed along the $\mathrm{x}$ axis.

\subsection{Daytime variation in SPAD readings}

Since SPAD readings are affected by leaf water content and irradiance, SPAD measurements might change throughout the day in parallel with the daily changes in photon flux density and leaf water status [9, 32, 33]. To test if there are diurnal variations in SPAD readings, SPAD measurements were made on the third topmost leaf of maize plants at two different times on the same day. In potted plants, there was no significant difference in extractable $\mathrm{Chl}$ content between leaves taken at midmorning and in the early afternoon, but SPAD values increased in the afternoon (Tab. II). RWC decreased and irradiance increased between measurement times (Tab. II). An increase of 2 SPAD units correlated with a $5 \%$ decrease in RWC between mid-morning and early afternoon. However, pot size can affect transpiration rates in maize [24], and, thereby, influence the daily changes in leaf RWC. Therefore, a more meaningful examination of daily variations in SPAD readings was conducted in the field. Measurements with the SPAD 502, Chl extraction and determinations of RWC and irradiance were made at mid-morning and in the early afternoon on maize plants growing under two $\mathrm{N}$ treatments $(0$ and $90 \mathrm{~kg} \mathrm{~N} \mathrm{ha}^{-1}$ applied at planting) (Tab. II). As in the pot experiment, average extractable $\mathrm{Chl}$ content did not change significantly between morning and afternoon in either $\mathrm{N}$ treatment. Irradiance increased by about $20 \%$ in the afternoon. In the non-fertilized plot, RWC decreased by $3 \%$ and SPAD readings increased by about 4 units after midday, compared with the morning measurements. In N-fertilized plots, SPAD values were 2.7 units higher after midday than in the morning, but this difference was not statistically significant. Unlike non-fertilized plants, RWC remained constant in $\mathrm{N}$-fertilized plants between the morning and afternoon measurements.

In general, SPAD readings in the afternoon were less sensitive to differences in Chl content than measurements taken in the morning (Fig. 3). The coefficients of determination $\left(R^{2}\right)$ for the relationship between SPAD readings and extractable chlorophyll content were higher for morning measurements. Moreover, the slope of the relationship between SPAD values and Chl content was different depending on the time of the day. Except for the $\mathrm{N}$-fertilized field treatment, the slopes were significantly higher $(P<0.05)$ for measurements made during the 
Table II. Daily changes in SPAD 502 readings in maize plants growing in pots and in the field under two N fertilization rates $\left(0\right.$ and $90 \mathrm{~kg} \mathrm{~N}$ ha $\left.^{-1}\right)$. Measurements were taken in the morning and afternoon on the same day. Values between parentheses represent the standard error of the mean $(n=25)$. For each of the three sets of data (i.e., potted plants and field-grown plants with or without fertilizer) values followed by the same letter are not significantly different at $P<0.05$.

\begin{tabular}{|c|c|c|c|c|c|c|}
\hline & \multirow{2}{*}{\multicolumn{2}{|c|}{ Potted plants }} & \multicolumn{4}{|c|}{ Field-grown plants } \\
\hline & & & \multicolumn{2}{|c|}{$0 \mathrm{~kg} \mathrm{~N} \mathrm{ha}^{-1}$} & \multicolumn{2}{|c|}{$90 \mathrm{~kg} \mathrm{~N} \mathrm{ha}^{-1}$} \\
\hline & morning & afternoon & morning & afternoon & morning & afternoon \\
\hline Chl content, $\mu \mathrm{g} \mathrm{cm}^{-2}$ & $16.1(0.7) \mathrm{a}$ & $17.5(0.5) \mathrm{a}$ & $20.0(0.7) \mathrm{a}$ & $21.0(0.8) \mathrm{a}$ & $27.5(0.7) \mathrm{a}$ & $28.8(1.0) \mathrm{a}$ \\
\hline SPAD units & $23.7(0.5) \mathrm{a}$ & $25.6(0.6) b$ & $30.6(0.9) \mathrm{a}$ & $34.6(0.9) \mathrm{b}$ & $40.1(0.7) \mathrm{a}$ & $42.9(1.2) \mathrm{a}$ \\
\hline RWC \% & $98(0.3) \mathrm{a}$ & $93(2.2) \mathrm{b}$ & $92(0.3) \mathrm{a}$ & $89(0.3) b$ & $91(0.9) \mathrm{a}$ & $91(0.3) \mathrm{a}$ \\
\hline $\begin{array}{l}\text { Irradiance } \\
\mu \mathrm{mol} \mathrm{m}^{-2} \mathrm{~s}^{-1} \\
\mathrm{~W} \mathrm{~m}^{-2}\end{array}$ & 579 & 748 & 582 & 712 & 582 & 712 \\
\hline
\end{tabular}
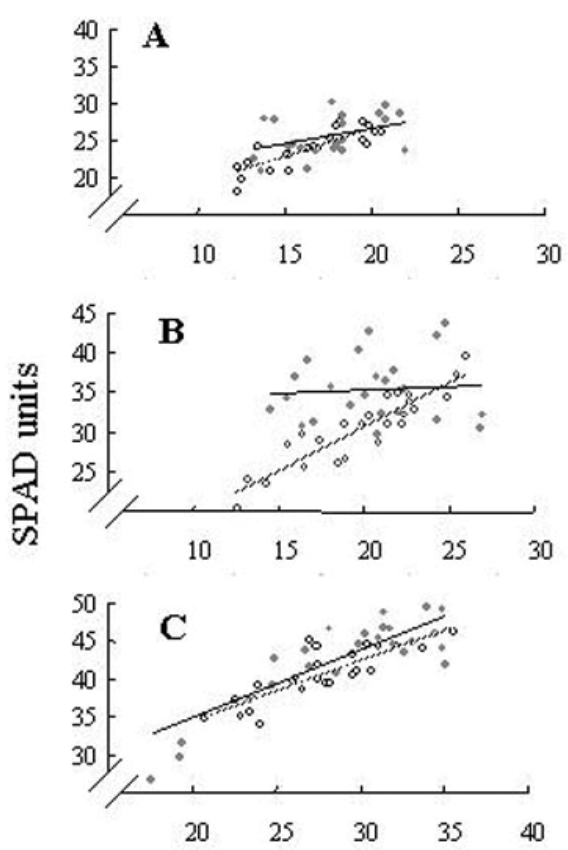

\section{Chlorophyll content $\left(\mu \mathrm{g} \mathrm{cm}^{-2}\right)$}

Figure 3. Daily changes in the relationship between extractable leaf chlorophyll content and SPAD readings in maize plants growing in pots (panel A) or in the field with 0 (panel B) or $90 \mathrm{~kg} \mathrm{~N} \mathrm{ha}^{-\mathrm{P}}$ (panel C). Measurements were taken in the morning (empty circles, dashed lines) and afternoon (closed circles, continuous lines). Lines show the best fit to a linear regression model (potted plants, morning $\mathrm{y}=$ $0.77 \mathrm{x}+11.06, \mathrm{R}^{2}=0.70$, afternoon $\mathrm{y}=0.40 \mathrm{x}+18.64, \mathrm{R}^{2}=0.14$, slopes significantly different at $P<0.05$; field-grown plants, $0 \mathrm{~kg} \mathrm{~N}$ $\mathrm{ha}^{-1}$ morning $\mathrm{y}=0.73 \mathrm{x}-2.52, \mathrm{R}^{2}=0.83$, afternoon $\mathrm{y}=0.06 \mathrm{x}+18.39$, $\mathrm{R}^{2}=0.00$, slopes significantly different at $P<0.05$; field-grown plants, $90 \mathrm{~kg} \mathrm{~N} \mathrm{ha}^{-1}$ morning y $=0.87 \mathrm{x}-7.77, \mathrm{R}^{2}=0.70$, afternoon $\left.y=0.65 x+0.70, R^{2}=0.58\right)$.

morning. Moreover, in the case of non-fertilized plots, the slope of the Chl/SPAD relationship was almost 0 for the set of measurements taken in the afternoon.

\section{DISCUSSION}

\subsection{Leaf water status interferes with SPAD measurements}

Changes in leaf water content within a physiologically meaningful range affected SPAD readings quite significantly. A decrease in RWC from 94 to $87.5 \%$ caused SPAD readings to increase by almost 3 units. Variations of this magnitude are not unusual under field conditions. Leaf RWC can be affected by ontogeny and by environmental stresses [29]. For example, significant changes in RWC occur as cereal leaves age, and these changes are exacerbated under water stress conditions [5]. Depending on the cultivar, wheat flag leaf RWC can decrease by about 10-20\% 15 days after withholding watering [3]. Probably more importantly, RWC can vary significantly throughout the day even in plants growing in the field under non-stressful conditions [9, 32, 33].

A decrease in RWC caused an increase in SPAD readings, i.e., a decrease in the apparent transmittance of leaves at $650 \mathrm{~nm}$ relative to $940 \mathrm{~nm}$. An increase in light reflectance may be a possible explanation for the decrease in apparent transmittance in slightly dehydrated leaves. Light is reflected at the interfaces of media with different refractive indexes, e.g., the cell wall-air interfaces in intercellular spaces [8]. Protoplast dehydration may increase the total surface area of the cell wall-air interface, thereby increasing leaf light reflectance, particularly in the visible region of the spectrum between 600 and $700 \mathrm{~nm}$ [6]. Since the SPAD meter cannot discriminate between a decrease in the amount of light reaching the sensor because of an increase in light absorption or reflection, increased reflectance at low RWC might be erroneously computed as a true decrease in transmittance and, therefore, as a higher leaf $\mathrm{Chl}$ content.

\subsection{SPAD readings change with irradiance}

In addition to the water status of the leaf, irradiance also interfered with SPAD measurements of Chl content. SPAD readings increased as irradiance decreased from 1100 to $650 \mu \mathrm{mol} \mathrm{m}{ }^{-2} \mathrm{~s}^{-1}$. Likewise, Hoel and Solhaug [10] reported that SPAD values increased in wheat leaves grown in a growth 
chamber as irradiance decreased from 600 to $12 \mu$ mol photons $\mathrm{m}^{-2} \mathrm{~s}^{-1}$, and our results now extend these observations to the higher irradiances that are more likely to occur under normal crop conditions. Leaf optical properties change with irradiance because chloroplasts move to the periclinal walls of cells to maximize light absorption at low irradiance, and to the anticlinal walls at high irradiance to reduce light absorptance as a photoprotective strategy to minimize the risk of photodamage $[13,14,21,26]$. For example, leaf transmittance can increase by up to $12 \%$ in Arabidopsis leaves at high irradiance [26]. Thus, changes in chloroplast distribution within the cell are a plausible explanation for the observed variations in SPAD readings at different irradiances.

\subsection{Diurnal changes in SPAD readings}

SPAD readings estimated leaf $\mathrm{Chl}$ content more accurately in measurements made in the morning, whereas measurements during the early afternoon often yielded SPAD readings that were poorly related, or completely unrelated (e.g., Fig. 3B) to the Chl content of the leaf. The time of measurement did not have much effect on measurements in fertilized maize plots, where leaf $\mathrm{Chl}$ content ranged between 20 and $35 \mu \mathrm{g} \mathrm{cm}^{-2}$ (Fig. 3C), but at lower Chl contents (i.e, potted plants and nonfertilized maize, Figs. 3A and B) the performance of the SPAD meter was much better in the morning than in the afternoon. Differences in irradiance between morning and afternoon measurements were relatively minor, and irradiance does not seem to be the cause of the altered SPAD readings in the afternoon because an increase in irradiance should work in the direction of reducing SPAD readings, whereas SPAD readings tended to increase in the afternoon. The poor response of SPAD readings to differences in extractable Chl content in potted plants and in the non-fertilized plots in the field may be due to the fact that these were the treatments where RWC changed between morning and afternoon. Although in general leaves with more available nitrogen lose more water and have lower midday leaf water potentials [32], field studies with maize have also shown higher midday leaf water potentials in $\mathrm{N}$-fertilized than in non-fertilized plants [30]. Thus, it is not completely unexpected that RWC did not vary between morning and afternoon in $\mathrm{N}$-fertilized maize plants. Although SPAD readings varied significantly between afternoon and morning measurements only in those treatments where RWC decreased after midday, other factors besides RWC may be involved, because when only RWC changes, SPAD readings increase but the slope of the relationship between SPAD and Chl content does not change (Fig. 1), whereas the slope of the SPAD vs. Chl relationship changed in measurements taken at different times of the day (Fig. 3).

\subsection{Significance of SPAD reading distortions}

We found that different SPAD values can be measured in the same leaves in response to changes in leaf water status and irradiance at the time of measurement. Measurements also differ significantly between morning and afternoon, and part of this daily fluctuation may be attributed to changes in leaf water content. The factors studied in this work can introduce a 24 units' bias in SPAD readings, which is quite significant in
SPAD-based $\mathrm{N}$ fertilization schemes. For example, Wu et al. [31] calculated that in order to achieve maximum lint production $24 \mathrm{~kg} \mathrm{~N} \mathrm{ha}^{-1}$ had to be added to a cotton crop for each SPAD unit below 32.4. A decrease of only 1-2 SPAD units measured 3-5 weeks after transplant translated into a $20 \%$ decrease in yields of air-cured leaves of tobacco [17]. Peng et al. [22] topdressed $\mathrm{N}$ on a rice crop every time the SPAD values of the five topmost leaves fell below 35. Although this protocol increased nitrogen-use efficiency, on several occasions $\mathrm{N}$ was topdressed when SPAD values were only 13 units below the reference reading, a difference that, based on our findings, might well be artifactual. While the use of sufficiency indexes relative to a well-fertilized strip helps to minimize the effects of cultivar, soil conditions other than $\mathrm{N}$ availability, etc., our results show that the accuracy of Chl estimation with the SPAD meter might improve significantly simply by making measurements early in the morning, when irradiance is low and RWC is likely to be at its daytime peak.

Acknowledgements: Thanks are due to M.Pardi and the staff of the experimental station of the Universidad Nacional de La Plata for allowing us to sample their maize crop. This work was funded by a grant from FONCYT, Argentina (PICT 08-03882). DEM was supported by a fellowship from FONCYT, Argentina. JJG is a researcher at CICBA, Argentina.

\section{REFERENCES}

[1] Adamsem F.J., Pinter P.J., Barnes E.M., LaMorte R.L., Wall G.W., Leavitt S.W., Kimball B.A., Measuring Wheat Senescence with a Digital Camera, Crop Sci. 39 (1999) 719-724.

[2] Araus J.L., Bort J., Ceccarelli S., Grando S., Relationship between leaf structure and carbon isotope discrimination in field grown barley, Plant Physiol. Biochem. 35 (1997) 533-541.

[3] Bajji M., Lutts S., Kinet J.M., Water deficit effects on solute contribution to osmotic adjustment as a function of leaf ageing in three durum wheat (Triticum durum Desf.) cultivars performing differently in arid conditions, Plant Sci. 160 (2001) 669-681.

[4] Blackmer T.M., Schepers J.S., Varvel G.E., Light reflectance compared with other nitrogen stress measurements in corn leaves, Agron. J. 86 (1994) 934-938.

[5] Blum A., Johnson J.W., Ramseur E.L., Toller E.W., The effect of a drying top soil and a possible non-hydraulic root signal on wheat growth, J. Exp. Bot. 42 (1991) 1225-1231.

[6] Carter G.A., McCain D.C., Relationship of leaf spectral reflectance to chloroplast water content determined using NMR microscopy, Remote Sens. Environ. 46 (1993) 305-310.

[7] Earl H.J., Tollenaar M., Maize leaf absorptance of photosynthetically active radiation and its estimation using a chlorophyll meter, Crop Sci. 37 (1997) 436-440.

[8] Grant L., Diffuse and specular characteristics of leaf reflectance, Remote Sens. Environ. 22 (1987) 309-322.

[9] Hirasawa T., Hsiao T.C., Some characteristics of reduced leaf photosynthesis at midday in maize growing in the field, Field Crop Res. 62 (1999) 53-62.

[10] Hoel B.O., Solhaug K.A., Effect of irradiance on chlorophyll estimation with the Minolta SPAD-502 leaf chlorophyll meter, Ann. Bot. 82 (1998) 389-392

[11] Hussain F., Bronson K.F., Singh Y., Singh B., Peng S., Use of chlorophyll meter sufficiency indices for nitrogen management of irrigated rice in Asia, Agron. J. 92 (2000) 875-879. 
[12] Inskeep W.P., Bloom P.R., Extinction coefficients of chlorophyll $\mathrm{a}$ and $\mathrm{b}$ in N,N-dimethylformamide and $80 \%$ acetone, Plant Physiol. 77 (1985) 483-485.

[13] Jeong W.J., Park Y.-I., Suh K.H., Raven J.A., Yoo O.J., Liu J.R., A large population of small chloroplasts in tobacco leaf cells allows more effective chloroplast movement than a few enlarged chloroplasts, Plant Physiol. 129 (2002) 112-121.

[14] Kasahara M., Kagawa T., Oikawa K., Suetsugu N., Miyao M., Wada M., Chloroplast avoidance movement reduces photodamage in plants, Nature 420 (2002) 829-832.

[15] Ladha J.K., Tirol-Padre A., Punzalan G.C., Castillo E., Singh U., Reddy C.K., Nondestructive estimation of shoot nitrogen in different rice genotypes, Agron. J. 90 (1998) 33-40.

[16] Maas S.J., Dunlap J.R., Reflectance, transmittance, and absorptance of light by normal, etiolated, and albino corn leaves, Agron. J. 81 (1989) 105-110.

[17] MacKown Ch.T., Sutton T.G., Using early-season leaf traits to predict nitrogen sufficiency of burley tobacco, Agron. J. 90 (1998) 21-27.

[18] Minolta Camera Co., Ltd., Manual for chlorophyll meter SPAD 502. Minolta, Radiometric Instruments Div., Osaka, Japan (1989).

[19] Ntamatungiro S., Normal R.J., McNew R.W., Wells B.R., Comparison of plant measurements for estimating nitrogen accumulation and grain yield by flooded rice, Agron. J. 91 (1999) 676-685.

[20] Ommen O.E., Donnelly A., Vanhoutvin S., van Oijen M., Manderscheid R., Chlorophyll content of spring wheat flag leaves grown under elevated $\mathrm{CO}_{2}$ concentrations and other environmental stresses within the 'ESPACE-wheat project', Eur. J. Agron. 10 (1999) 197-203.

[21] Park Y.I., Chow W.S., Anderson J.M., Chloroplast movement in the shade plant Tradescantia albiflora helps protect photosystem II against light stress, Plant Physiol. 111 (1996) 867-875.

[22] Peng S., Garcia F.V., Laza R.C., Sanico A.L., Visperas R.M., Cassman K.G., Increased N-use efficiency using a chlorophyll meter on highyielding irrigated rice, Field Crops Res. 47 (1996) 243-252.
[23] Piekielek W.P., Fox R.H., Toth J.D., Macneal K.E., Use of a chlorophyll meter at the early dent stage of corn to evaluate nitrogen sufficiency, Agron. J. 87 (1995) 403-408.

[24] Ray J.D., Sinclair T.R., The effect of pot size on growth and transpiration of maize and soybean during water deficit stress, J. Exp. Bot. 49 (1998) 1381-1386.

[25] Shapiro C.A., Using a chlorophyll meter to manage nitrogen applications to corn with high nitrate irrigation water, Commun. Soil Sci. Plant Anal. 30 (1999) 1037-1049.

[26] Trojan A., Gabrys H., Chloroplast distribution in Arabidopsis thaliana (L.) depends on light conditions during growth, Plant Physiol. 111 (1996) 419-425.

[27] Vidal I., Longeri L., Hétier J.M., Nitrogen uptake and chlorophyll meter measurements in spring wheat, Nutr. Cycl. Agroecosyst. 55 (1999) 1-6.

[28] Wardlaw I.F., The effect of water stress on translocation in relation to photosynthesis and growth, Aust. J. Biol. Sci. 20 (1967) 25-39.

[29] Wayne R.J., Ritchie J.T., Influence of soil water stress on evaporation, root absorption, and internal water status of cotton, Plant Physiol. 48 (1971) 783-788.

[30] Wolfe D.W., Henderson D.W., Hsiao T.C., Alvino A., Interactive water and nitrogen effects on senescence of maize. I. Leaf area duration, nitrogen distribution, and yield, Agron. J. 80 (1988) 859864.

[31] Wu F., Wu L., Xu F., Chlorophyll meter to predict nitrogen sidedress requirements for short-season cotton (Gossypium hirsutum L.), Field Crops Res. 56 (1998) 309-314.

[32] Yang J., Zhang J., Huang Z., Zhu Q., Wang L., Remobilization of carbon reserves is improved by controlled soil-drying during grain filling of wheat, Crop Sci. 40 (2000) 1645-1655.

[33] Yang J., Zhang J., Wang Z., Zhu Q., Liu L., Water deficit-induced senescence and its relationship to the remobilization of pre-stored carbon in wheat during grain filling, Agron. J. 93 (2001) 196-206. 